\title{
Günübirlik anestezi uygulamalarımız ve gelişen komplikasyonlar
}

\section{Our practices of outpatient anesthesia and complications}

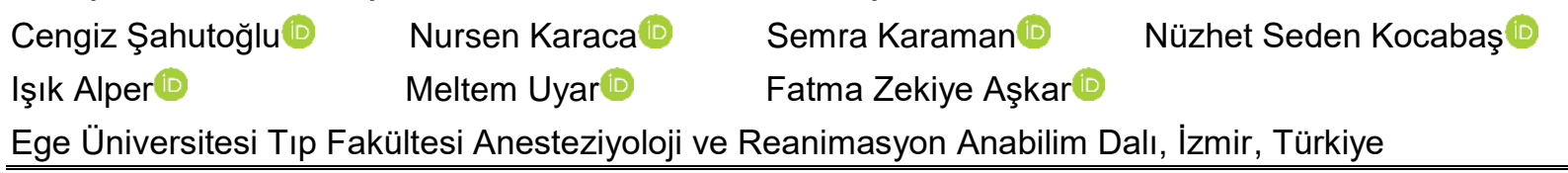

\section{öz}

Amaç: Tıbbi teknolojideki ve monitörizasyondaki gelişmeler günübirlik cerrahi uygulamalarında hızlı bir artışa neden oldu. Bu çalışmada günübirlik anestezi sonuçlarımızın sunulması hedeflendi.

Gereç ve Yöntem: Günübirlik cerrahi geçiren 907 hasta prospektif gözlemsel olarak çalışmaya alındı. Acil hastalar, ameliyathane dışı anestezi uygulamaları ve anestezi ekibinin eşlik etmediği operasyonlar çalışma dışı bırakıldı. Hastalara yapılacak işleme göre genel anestezi, rejyonal anestezi veya sedoanaljezi uygulandı. Komplikasyonlarla ilişkili risk faktörleri ile demografik veriler, anestezi yöntemi, intraoperatif ve postoperatif değişkenler arasında istatiksel anlamlılık araştıııldı.

Bulgular: Hastanemizde Şubat 2020'de 2194 hasta operasyona alındı. Hastalardan 907'si (\%41,3) günübirlik kriterlerini karşılamaktaydı. Hastaların \%26,8'ini (243 hasta) pediyatrik hastalar oluşturmaktaydı. Göz hastalıkları (\%67) en sık günübirlik operasyon yapılan klinik oldu. İntratrakeal genel anestezi $(\% 36,7)$, en sık uygulanan anestezi şekliydi. İntraoperatif ve postoperatif komplikasyon sırasıyla hastaların \%2,9'da ve \%1,9'da gelişti. Operasyonun endoskopik yapılması (OR: 4,357 [1,909$9,943], p<0,001)$ ve bazal kalp hızı yükseklikleri (OR:1,030 [1,009-1,052], $p=0,006$ ) peroperatif komplikasyonlar ile ilişkiliydi.

Sonuç: Operasyonun endoskopik uygulanması ve bazal kalp hızı yüksekliği peroperatif komplikasyon ile ilişkili iken; anestezi türü ile komplikasyon arasında anlamlı ilişki olmadığı saptandı. Hızlı ve kısa etkili anesteziklerin, analjeziklerin ve nöromuskuler blokörlerin yanı sıra geliştirilmiş monitörizasyon yöntemlerinin kullanımı perioperatif anestezi komplikasyonlarını azaltacaktır.

Anahtar Sözcükler: Günübirlik cerrahi; ayaktan hasta takibi; anestezi, postoperatif komplikasyonlar.

\section{ABSTRACT}

Aim: Advances in medical and monitoring technologies have led to a rapid increase in daily surgical practices. In this study, it is aimed to present our outpatient anesthesia results.

Materials and Methods: In the prospective observational study, 907 patients who had outpatient surgery were included. Emergency patients, non-operating room anesthesia applications and operations not accompanied by the anesthesia team were excluded from the study. General anesthesia, regional anesthesia or sedo-analgesia were applied to the patients according to the procedure performed. Statistical significance was investigated between risk factors associated with complications and demographics data, anesthetic method, intraoperative and postoperative variables.

Results: In February 2020, 2194 patients were operated in our hospital and 907 (41.3\%) of the patients met the outpatient criteria. $26.8 \%$ of the patients (243 patients) were pediatrics. Ophthalmological procedures were the most frequent ones (67\%). The most common types of anesthesia was intratracheal general anesthesia (36.7\%). 
Intraoperative and postoperative complications developed respectively in $2.9 \%$ and in $1.9 \%$ of the patients. It was found that the complications were associated with endoscopic operations (OR: 4.357 [1.909-9.943], $p<0.001$ ) and high basal heart rate (OR:1.030 [1.009-1.052], $p=0.006)$.

Conclusion: While the endoscopic application of the operation and high basal heart rate were associated with complication, no complication-associated anesthesia method was found. The use of fast and short-acting anesthetics, analgesics and neuromuscular blockers, as well as improved monitoring methods, will reduce anesthesia complications during recovery.

Keywords: Outpatient surgery; outpatient monitoring; anesthesia; postoperative complications.

\section{GíRiş}

Günübirlik cerrahi, operasyon süresinin kısa olduğu, operasyon esnasında kanama ve sıvı kaybının olmadığı ayrıca hastaların cerrahi sonrası aynı gün evine gönderilebildiği uygulamalardır (1). Hastane enfeksiyonlarını, postoperatif komplikasyonları, hastane maliyetlerini, hastaların evlerinden ve ailelerinden ayrıma anksiyetelerini azaltması; ayrıca, hızı taburculuğu sağlayarak hasta birikimini önlemesi nedeniyle günübirlik cerrahiye eğilim her geçen gün artmaktadır. Günümüzde elektif vakaların \%60-70'e yakını günübirlik cerrahi olarak yapılmaktadır $(1,2)$. Son 30 yıl içinde günübirlik cerrahi merkezlerinin hasta yelpazesi sağlıklı kişilere uygulanan basit girişimlerden, ek hastalığı olan hastalara ve daha komplike işlemlere doğru genişlemiştir (2).

Günübirlik girişimlerin başarısı ve perioperatif risklerin en aza indirilmesi doğru hasta seçimine bağlıdır. Cerrahi girişimin türü ve süresi, olası kan kaybı, Amerikan Anestezistler Birliği (ASA) risk sınıflaması, anestezi tekniği, ekipman yeterliliği ve sosyal faktörler hasta seçiminde önemlidir. Bu yüzden girişim öncesi ayrıntılı preoperatif anestezik değerlendirme ile yüksek riskli hastaların doğru hazırlanması sağlanmalıdır. En uygun hastalar ASA I ve II grubu olmakla birlikte, günümüzde iyi hazırlanmış ASA III grubu hastalar da günübirlik cerrahiye alınabilmektedir (3).

Türk Anesteziyoloji ve Reanimasyon Derneği'nin 2015 yılında yayınladığı kılavuzda günübirlik cerrahi için uygun hastalar belirlenmiştir. Buna göre, uygulanacak cerrahi girişim uygun bir sürede bitirilmeli ( 3,5 saat veya yarım mesai gününü aşmamalı), operasyon kan veya SıVı kaybına neden olmamalı, postoperatif kanama riski minimal olmalı, postoperatif havayolu güvenliği açısından minimal risk olmalı, postoperatif ağrı evde kontrol altına alınabilmeli, bulantı-kusma olmamalı, dren veya kateter kullanmayı gerektirecek bir işlem olmamalı, hasta hareketini kısıtlamayan bir girişim olmalı, postoperatif bakım hastanın kendisi ya da bir yakını tarafından yapılabilmeli ve hastanın oral alımı hızlı geri dönebilmelidir. Hastalar mümkün olduğu kadar erken operasyona alınarak postanestezik bakım ünitesi (PABÜ) süresinin uzatılması tavsiye edilmektedir (3). Hayati tehlike oluşturan sistemik hastalık varlığında (regüle olmayan diyabetes mellitus, alerjik astım, unstabil anjina öyküsü gibi), semptomatik kardiyovasküler hastalığa neden olan morbid obezitede (BMI $\geq 50$ $\left.\mathrm{kg} / \mathrm{m}^{2}\right)$, prematüre bebeklerde, santral etkili ilaç (mono amin oksidaz inhibitörleri, kokain gibi) kullanan hastalarda ve hastanın sosyal desteğinin olmaması gibi durumlarda günübirlik cerrahi planlanması yapılmamalıdır (3).

Biz bu çalışma ile yeni kurulan merkezi ameliyathanemiz öncesinde günübirlik anestezi uygulamalarımızı ve gelişen komplikasyonları araştırmayı hedefledik. Çalışmanın primer hedefi günübirlik anestezi oranlarımızı saptamakdı. Sekonder hedef ise gelişen komplikasyonları ve risk faktörlerini belirlemekti.

\section{GEREÇ ve YÖNTEM}

Fakültemiz Klinik Araştırmalar Etik Kurulu'nun onayı (Karar numarası:15-2/9, tarihi: 09/02/2015) ve hastalardan ya da ebeveynlerinden aydınlatılmış yazılı onam formu alındıktan sonra, ardışık olarak bir aylık dönemde günübirlik cerrahiye alınanan 907 hasta prospektif gözlemsel olarak çalışmaya dahil edildi. Günübirlik cerrahi olarak planlanmayan tüm hastalar, anestezi ekibinin eşlik etmediği hasta grupları (cerrahi ekibin tek başına işlem yaptığı hasta grubu), ameliyathane dışı uygulamalar, acil hastalar, verileri eksik tutulan hastalar, hastanın veya ebeveyninin çalışmadan çıkmak istemesi araştırmadan dışlama kriteri olarak kabul edildi. Çalışmaya dahil edilen klinikler ve prosedürleri şu şekildedir:

1. Çocuk Cerrahisi: Biyopsi, sünnet, endoskopik işlemler, ingunal herni onarımı, orşiopeksi, basit 
sütür-atılması ve basit yanık işlemleri, genel anestezi altında muayene, diş tedavisi

2. Üroloji: Sünnet, sistoskopi, vazektomi, litotripsi, prostat biyopsisi

3. Kulak Burun Boğaz: Adenoidektomi, tonsillektomi, yabancı cisim çıkarma, laringoskopi, polipektomi.

4. Kadın Hastalıkları ve Doğum: Küretaj, biyopsi, abse drenajı, polipektomi, tüp ligasyonu, histeroskopi

5. Genel Cerrahi: Biyopsi, endoskopi, anal fistül eksizyonu, hemoroidektomi, herni onarımı

6. Ortopedi: Artroskopi, biyopsi, karpal tünel operasyonu, kapalı redüksiyonlar, debritman, tetik parmak, basit amputasyonlar, el kesisi onarımı, el kırıkları, alçılama

7. Plastik Cerrahi: Rinoplasti (basit revizyon), otoplasti, skar eksizyonu, basit sütürler

8. Beyin Cerrahisi: Kas biyopsisi, sinir biyopsisi, trigeminal nevralji enjeksiyonu

9. Göz Hastalıkları: Göz dibi muayenesi, şelazyon eksizyonu, kriyoterapi

10. Kalp Damar Cerrahisi: Varis operasyonları

11. Göğüs Cerrahisi: Biyopsi, basit yüzeyel kitle eksizyonu.

Preoperatif anestezik değerlendirilme sonrası operasyon günü yaşına uygun olarak preoperatif açlık süresi istendi ve gereğinde hastalara premedikasyon uygulandı. Tüm hastalar elektrokardiyografi (EKG), pulse oksimetre, invaziv olmayan tansiyon manşonu ile monitörize (Drager Infinity Acute Care System, Dräger Medical, Lubeck, Germany) edildi. Genel anestezi uygulanan hastalar ise mekanik ventilatör (Dräger Perseus A500 (Perseus) Anesthetic Workstation, Dräger Medical, Lubeck, Germany) desteğine alındı ve anestezi idamesi inhalasyon anestezikleri (sevofluran veya desfluran) veya intravenöz anestezikler ile (propofol, remifentanil) ile sağlandı. Rejyonal anestezide ise lokal anestezikler (beraberinde adjuvanlar) kullanıldı. Operasyon bitiminde hastalara ağrı kontrolü amacıyla uygun analjezik tedavisi uygulandı. Hastalar işlem (veya ekstübasyon) sonrası uygulanan operasyon ve genel durumuna göre uygun postoperatif bakım ünitesine (PABÜ) nakledildi. Anestezi veya cerrahi ekibi tarafından hastaneden taburculuğu uygun görülmeyen hastalar günübirlikten çıkarılıp hastaneye yatırıldı.
Hastaların demografik ve bazal hemodinamik değişkenleri, ek hastalıkları, ASA skoru (Tablo-1), anestezi türü, kullanılan anestezik ve diğer ilaçlar, sıvı ve analjezik tedavisi, operasyon ve anestezi süresi, intraoperatif ve postoperatif komplikasyonlar, taburculuk veya hastaneye yatışı kaydedildi. İstatistiksel analiz için SPSS 21,0 (Windows için, SPSS inc., IL, ABD) programı kullanıldı. Veriler ortalama \pm standart sapma (SS), median (minimum-maksimum) veya yüzde $(\%)$ olarak ifade edildi. Verilerin normal dağılımı Kolmogorov-Smirnov testi ile analiz edildi. İstatistiksel analizlerde gruplar arası karşılaştırmalarda kategorik değişkenler için KiKare veya Fisher Exact testleri, normal dağılım gösteren niceliksel değişkenler için bağımsız örnekli t testi veya Paired-Sample T Test; normal dağılım göstermeyenlerde Mann-Whitney $U$ testi ve Wilcoxon Testi kullanıldı. Komplikasyonlarla ilişkili risk faktörlerini saptamak için logistik regresyon analizi uygulandı. İstatistiksel olarak $p<0,05$ anlamlı olarak kabul edildi.

Tablo-1. ASA (Amerikan Anestezistler Birliği) risk sınıflaması ve perioperatif mortalite oranları

ASA I. Cerrahi patoloji dışında bir hastalık veya sistemik sorunu olmayan sağlıklı kişi

(\% 0,06-0,08).

ASA II. Cerrahi girişim gerektiren nedene veya başka bir hastalığa (hafif derecede anemi, kronik bronşit, amfizem, hipertansiyon, şişmanlık, diyabet gibi) bağı hafif bir sistemik hastalığı olan kişi (\% 0,27-0,4).

ASA III. Aktivitesini sınırlayan, ancak güçsüz bırakmayan hastalığı (hipovolemi, kalp yetmezliği, geçirilmiş miyokard infarktüsü, ileri diyabet, sınırlı akciğer fonksiyonu) olan kişi (\%1,8-4,3).

ASA IV. Gücünü tamamen yitirmesine neden olup hayatına sürekli bir tehdit oluşturan bir hastalığı (şok, dekompanze kalp yetmezliği veya solunum sistemi hastalığı, böbrek yetmezliği ve karaciğer yetmezliği gibi) olan kişi (\%7,8-23).

ASA V. Ameliyat olsa da olmasa da 24 saatten fazla yaşaması beklenmeyen, son ümit olarak cerrahi girişim yapılacak olan ölüm halindeki kişi $(\% 9,4-51)$.

ASA VI. Beyin ölümü gelişmiş organ donörü olabilecek hastalar bu grupta yer almaktadır

Acil cerrahi gereken hastanın sınıflama numarasından sonra "E" harfi eklenmektedir. ASA IIE gibi. 


\section{BULGULAR}

Hastanemizde 1 Şubat 2020-29 Şubat 2020 tarihleri arasında 2194 hasta operasyona alındı. Hastalardan 907'si $(\% 41,3)$ çalışmanın kriterlerini karşılamaktaydı. Göz hastalıkları $(\% 67,3)$, Çocuk Cerrahisi $(\% 62,4)$ ve Kulak Burun Boğaz
Hastalıkları $(\% 59,6)$ en sık günübirlik işlem yapılan klinikler oldu. Kalp ve Damar Cerrahisi $(\% 11,5)$, Göğüs Cerrahisi $(\% 8,7)$ ve Beyin Cerrahisi $(\% 3,8)$ ise günübirlik işlem oranları en düşük olan kliniklerdi (Tablo-2).

Tablo-2. Çalışma dönemindeki toplam ve günübirlik hasta sayıları.

\begin{tabular}{|c|c|c|}
\hline & $\begin{array}{c}\text { Günübirlik } \\
\text { Hasta (n, \%) }\end{array}$ & $\begin{array}{c}\text { Toplam } \\
\text { Hasta (n) }\end{array}$ \\
\hline Göz Hastalıkları & $70(67,3)$ & 104 \\
\hline Çocuk Cerrahisi & $138(62,4)$ & 221 \\
\hline Kulak Burun Boğaz & $121(59,6)$ & 203 \\
\hline Plastik Cerrahi & $51(50)$ & 102 \\
\hline Üroloji & $111(48,7)$ & 228 \\
\hline Kadın Hastalıkları ve Doğum & $190(41,3)$ & 460 \\
\hline Ortopedi & $95(34,2)$ & 278 \\
\hline Genel Cerrahi & $112(31,4)$ & 357 \\
\hline Kalp ve Damar Cerrahisi & $13(11,5)$ & 113 \\
\hline Göğüs Cerrahisi & $2(8,7)$ & 23 \\
\hline Beyin Cerrahisi & $4(3,8)$ & 105 \\
\hline Toplam & 907 & 2194 \\
\hline
\end{tabular}

Veriler sayı (n) ve yüzde (\%) olarak verilmiştir.

Tablo-3. Hasta grupları ve ASA dağılımları.

\begin{tabular}{lcccc}
\hline Grup & $\begin{array}{c}\text { ASA I } \\
(\mathbf{n}, \%)\end{array}$ & $\begin{array}{c}\text { ASA II } \\
(\mathbf{n}, \%)\end{array}$ & $\begin{array}{c}\text { ASA III } \\
(\mathbf{n}, \%)\end{array}$ & $\begin{array}{c}\text { Toplam } \\
(\mathbf{n}, \%)\end{array}$ \\
\hline Çocuk & $169(69,6)$ & $70(28,8)$ & $4(1,6)$ & $243(100)$ \\
Erişkin & $303(45,6)$ & $351(52,9)$ & $10(1,5)$ & $664(100)$ \\
\hline
\end{tabular}

Veriler sayı (n) ve yüzde (\%) olarak verilmiştir.

Tablo-4. Kliniklere göre demografik veriler.

\begin{tabular}{|c|c|c|c|c|}
\hline $\begin{array}{c}\text { Klinik } \\
\text { (n=Hasta sayısı) }\end{array}$ & $\begin{array}{c}\text { Yaş } \\
\text { median (min-mak) }\end{array}$ & $\begin{array}{l}\text { Cinsiyet } \\
\text { (Kadın,\%) }\end{array}$ & $\begin{array}{l}\text { Ağırlık } \\
(\mathrm{Kg})\end{array}$ & $\begin{array}{c}\text { ASA } \\
(\mathrm{I} / \mathrm{II} / \mathrm{III})\end{array}$ \\
\hline Göz Hastalıkları $(n=70)$ & 5,5 (4 ay-85 yıl) & 39 & $19(4,7-94)$ & $43 / 26 / 1$ \\
\hline Çocuk Cerrahisi $(n=138)$ & 6,5 (2 ay-19 yıl) & 21 & $21(2,5-103)$ & $89 / 46 / 3$ \\
\hline $\operatorname{KBB}(n=121)$ & 31 (1 ay-82 yıl) & 52 & $67(5-105)$ & $75 / 45 / 1$ \\
\hline Plastik Cerrahi $(n=51)$ & 46 (1.5-76 yıl) & 53 & $70(9-89)$ & $21 / 30 / 0$ \\
\hline Üroloji (n=111) & 59 (10 ay-89 yıl) & 26,1 & $75(8-140)$ & $38 / 70 / 3$ \\
\hline KH ve Doğum $(n=190)$ & 44 (21-85 yıl) & 100 & $70(41-105)$ & $99 / 91 / 0$ \\
\hline Ortopedi (n=95) & 41 (5 ay-84 yıl) & 45 & $69(6,5-107)$ & $63 / 28 / 4$ \\
\hline Genel Cerrahi $(n=112)$ & 52,5 (18-82 yıl) & 64 & $75(47-132)$ & $41 / 69 / 2$ \\
\hline $\operatorname{KDC}(n=13)$ & 51 (26-75 yıl) & 46 & $78(65-115)$ & $3 / 10 / 0$ \\
\hline Göğüs Cerrahisi (n=2) & 47,5 (41-54 yıl) & 0 & $88(78-97)$ & $0 / 2 / 0$ \\
\hline Beyin Cerrahisi $(n=4)$ & 23,5 (9 ay-70 yıl) & 25 & $34(7-75)$ & $0 / 4 / 0$ \\
\hline
\end{tabular}

Veriler median (min-mak), sayı (n) ve yüzde (\%) olarak verilmiştir. KBB; Kulak Burun Boğaz Hastalıkları, KH ve Doğum; Kadın Hastalıkları ve Doğum, KDC; Kalp ve Damar Cerrahisi, min; minumum, mak; maksimum. 
Hastaların \%26,8'i (243 hasta) pediyatrik yaş grubundan ve \%53,7'si (487 hasta) kadınlardan oluşmaktaydı. Hastaların ortalama yaşları $37,3 \pm 23,8$ yıl (min-mak: 10 ay-84 yaş, median: 40 yıl), kiloları $63 \pm 25 \mathrm{~kg}$ (min-mak: $2,5-132 \mathrm{~kg}$, median: $67 \mathrm{~kg}$ ), boyları $155 \pm 27 \mathrm{~cm}$ (min-mak: 50$193 \mathrm{~cm}$, median: $164 \mathrm{~cm}$ ) ve vücut kitle indeksi

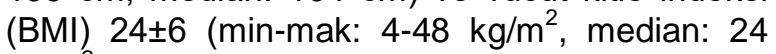
$\mathrm{kg} / \mathrm{m}^{2}$ ) idi. Hastaların \%52'si (472 hasta) ASA I, $\% 46,4$ 'ü ASA II, \%1,5'i ASA III grubundaydı. Çocuk hastalar genellikle ASA I grubunda iken, erişkin hastaların çoğunluğu ASA II grubundaydı $\left(x^{2}: 82,68, p<0,001\right)$ (Tablo-3). Çocuk hastalarda erkek cinsiyet $(\% 71,2)$, erişkinlerde ise kadın cinsiyet $(\% 62,8)$ daha fazlaydı $\left(X^{2}: 41,75\right.$, $\mathrm{p}<0,001)$ (Tablo-4).

Hastalarda en sık görülen üç ek hastalık sırasıyla hipertansiyon $(\% 15,7)$, diyabetes mellitus $(\% 9,8)$ ve tiroid hastalıkları $(\% 7,3)$ olarak sıralandı. Sigara kullanımı hastaların \%16,4'ünde (149 hasta) mevcuttu (Tablo-5). Hastaların sadece $\% 10,5$ 'ine (95 hasta) premedikasyon uygulandı. Bu hastaların \%93,7'si çocuk hasta grubundaydı $(p<0,001)$. Premedikasyon uygulanan 95 hastanın $\% 87,4$ 'ünde oral yol ile midazolam, geri kalan \%12,6'sında ise intravenöz propofol (11 hasta) veya ketamin (1 hasta) tercih edildi. Hiçbir hastaya intramuskuler veya rektal yol ile premedikasyon uygulanmadı.

Tablo-5. Hastaların preoperatif dönemdeki yandaş hastalıkları.

\begin{tabular}{lccc}
\hline Sigara Kullanmı & $149(16,4)$ & Nörolojik Hastalıklar & $39(4,3)$ \\
Solunum Sistemi Hastalıkları & $55(5)$ & SVH & $9(1)$ \\
KOAH & $12(1,3)$ & Epilepsi & $11(1,2)$ \\
Alerjik Astım & $28(3,1)$ & Demans & $2(0,2)$ \\
Diğer & $5(0,6)$ & Kas hastalıkları & $5(0,6)$ \\
Kardiyovasküler hastalıklar & $172(19)$ & Endokrin Hastalıkları & $148(16,3)$ \\
Hipertansiyon & $142(15,7)$ & Diyabetes Mellitus & $89(9,8)$ \\
Koroner Arter Hastalığı & $31(3,4)$ & Hipertiroidi/Hipotiroidi & $66(7,3)$ \\
Kalp Kapağı Hastalığı & $7(0,8)$ & Gastrointestinal & $27(3)$ \\
Aritmi & $13(1,4)$ & Hastalıklar & $131(14,4)$ \\
Periferik arter hastalığı & $5(0,6)$ & Diğer Hastalıklar & \\
Renal hastalıklar & $12(1,3)$ & &
\end{tabular}

Veriler sayı (n) ve yüzde (\%) olarak verilmiştir. KOAH; Kronik obstrüktif akciğer hastalığı, KBY; Kronik böbrek yetmezliği, SVH Serebrovasküler hastalık.

Tablo-6. Hastalardaki anestezi uygulamalarının dağıımı.

\begin{tabular}{lccc}
\hline Anestezi Şekli & Toplam (n, \%) & Çocuk & Erişkin \\
\hline Genel Anestezi & $667(73,5)$ & $194(21,4)$ & $473(52,1)$ \\
İntra-trakeal genel anestezi & $333(36,7)$ & $115(12,7)$ & $218(24)$ \\
Laringeal Maske & $164(18,1)$ & $60(6,6)$ & $104(11,5)$ \\
Maske Anestezisi & $170(18,7)$ & $19(2,1)$ & $151(16,6)$ \\
Sedo-Analjezi (MAB) & $65(7,2)$ & $46(5,1)$ & $19(2,1)$ \\
Rejyonal bloklar & $175(19,3)$ & $3(0,3)$ & $172(19)$ \\
Spinal anestezi & $130(14,3)$ & $1(0,1)$ & $129(14,2)$ \\
Periferik sinir blokları & $45(5)$ & $2(0,2)$ & $43(4,8)$ \\
\hline
\end{tabular}

Veriler sayı ve yüzde (n, \%) olarak verilmiştir. MAB; monitörize anestezik bakım. 
Hastaların operasyona giriş ve operasyon sonu ortalama tansiyon değerleri, kalp hızı değerleri ve oksijen satürasyonu değerleri sırasıyla $90 \mathrm{mmHg}$ $(52-140)$ / $80 \mathrm{mmHg}$ (52-120), $\mathrm{p}<0,001 ; 95$ atım/dk (60-160) / 90 atım/dk (60-160), $p=0,001$; \%99 (92-100) / \%100 (95-100), $p<0,001$ olarak kaydedildi. Hastaların \%99,7'sinde sıvı tedavisinde kristaloid kullanıldı (min-mak: 0-3000 $\mathrm{mL}$, median: $500 \mathrm{~mL}$ ). Sadece üç hastada kolloid kullanımı mevcut idi. Hiçbir hastada kan transfüzyonu intiyacı olmadı.

Hastaların \%19,3'üne (175 hasta) rejyonal blok ile operasyon uygulandı. En sık uygulanan blok ise 130 hasta ile spinal anestezi oldu. Epidural anestezi veya kombine epidural-spinal anestezi günübirlik vakalarda tercih edilmedi. Spinal anestezi veya periferik blok uygulanan hastalardan 14'üne yetersiz blok veya hasta uyumsuzluğu nedeniyle sedasyon uygulandı. Pediyatrik hastalarda ise rejyonal anestezi uygulamaları çok az tercih edildi $\left(X^{2}: 69,52\right.$; p<0,001) (Tablo-6).
Genel anestezi uygulanan hastaların sadece $\% 54,1^{\prime}$ inde (361 hasta) nöromuskuler bloker uygulandı. Nöromuskuler blokör olarak rokuronyum kullanıldı. Rokuronyum kullanılan hastaların \%46'sında nöromuskuler blokajın geri çevrilmesi için ilaç gereksinimi olmazken, hastaların \%51,2'sine sugammadeks ve $\% 2,8$ 'sine ise neostigmin uygulandı $\left(X^{2}: 372\right.$, $p<0,001)$. Intraoperatif analjezi amacıyla hastaların \%46,4'ünde opioid kullanıldı. En sık olarak remifentanil $(\% 27,6)$, fentanil $(\% 12,5)$ ve remifentanil-fentanil kombinasyonu $(\% 6,4)$ tercih edildi. Remifentanil kullanımı anlamlı olarak yüksekti $\left(X^{2}: 170, p<0,001\right)$. Lokal anesteziklerden ise bupivakain $(\% 21,4)$, bupivakain+prilokain $(\% 1,3)$, lidokain $(\% 1)$ ve prilokain $(\% 0,8)$ kullanıldı. Hastaların operasyon süresi (min-mak: 7-350 dk, median: $40 \mathrm{dk}, \mathrm{p}=0,91$ ) ve anestezi süreleri (min-mak:10-360 dk, median: $50 \mathrm{dk}$, $\mathrm{p}=0,609$ ) farklı anestezi uygulamalarında benzerdi (Tablo-7).

Tablo-7. Anestezi türlerine göre operasyon ve anestezi süreleri.

\begin{tabular}{|c|c|c|}
\hline \multicolumn{2}{|c|}{ Operasyon Süresi } & $\begin{array}{c}\text { Anestezi Süresi } \\
\text { Ort. } \pm \text { ss (median, min-mak) }\end{array}$ \\
\hline Genel Anestezi & $51 \pm 43(35,7-350)$ & $59 \pm 44(45,10-360)$ \\
\hline ITGA & $78 \pm 46(70,10-350)$ & $87 \pm 46(80,15-360)$ \\
\hline LMA & $41 \pm 35(35,15-165)$ & $49 \pm 21(45,20-185)$ \\
\hline Maske & $18 \pm 9(15,7-60)$ & $23 \pm 10(20,10-70)$ \\
\hline Sedo-Analjezi & $22 \pm 15(20,7-110)$ & $26 \pm 16(25,10-120)$ \\
\hline Rejyonal blok & $50 \pm 27(40,10-180)$ & $58 \pm 28(50,15-185)$ \\
\hline Spinal Anestezi & $49 \pm 27(40,10-150)$ & $57 \pm 28(50,15-160)$ \\
\hline Periferik blok & $51 \pm 40(43,15-180)$ & $59 \pm 41(53,20-185)$ \\
\hline Toplam & $51 \pm 40(40,7-350)$ & $59 \pm 41(50,10-360)$ \\
\hline \multicolumn{3}{|c|}{ 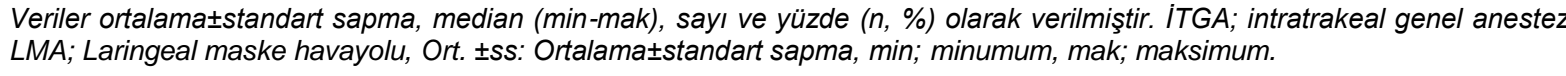 } \\
\hline \multicolumn{2}{|c|}{ Kullanılan Analjezik } & n (\%) \\
\hline \multicolumn{2}{|l|}{ Ek analjezik yok } & $503(55,5)$ \\
\hline \multicolumn{2}{|l|}{ Parasetamol } & $328(36,2)$ \\
\hline \multicolumn{2}{|l|}{ Tramadol } & $118(13)$ \\
\hline \multicolumn{2}{|c|}{ Non-steroid anti-inflamatuar ilaçlar } & $107(11,8)$ \\
\hline \multicolumn{2}{|c|}{ Analjezi amaçlı blok (+ Genel anestezi) } & $43(4,7)$ \\
\hline \multicolumn{2}{|l|}{ Morfin } & $5(0,6)$ \\
\hline
\end{tabular}

Veriler sayı ve yüzde (n, \%) olarak verilmiştir. 
Tablo-9. Günübirlik işlemlerde komplikasyonlarla ilişkili risk faktörleri.

\begin{tabular}{lccc}
\hline & Odds oranı (OR) & $\% 95$ GA & p değeri \\
\hline Endoskopik işlem & 4,357 & $1,909-9,943$ & $<0,001^{*}$ \\
Bazal HR & 1,030 & $1,009-1,052$ & $0,006^{*}$ \\
Bazal SpO & 0,691 & $0,470-1,017$ & 0,061 \\
\hline
\end{tabular}

"p<0,05, HR; kalp atım hızı (atım/dk), SpO z; oksijen satürasyonu (\%), \%95 GA; \%95 güven aralığı.

Hastaların \%55,5'inde postoperatif dönemde ek analjezik intiyacı olmadı. Postoperatif analjezi amacıyla en sık kullanılan analjezikler parasetamol $(\% 36,2)$ ve tramadol (\%13) oldu. Genel anestezi uygulanan hastalardan 43'üne $(\% 5,9)$ ise analjezi amaciyla santral blok veya periferik sinir bloğu uygulandı. En sık analjezi amacıyla kullanılan blok ise penil blok (34 hastada) oldu (Tablo-8).

Peroperatif dönemde 41 hastada 44 adet komplikasyon gelişti. İntraoperatif komplikasyon ve postoperatif komplikasyon sırasıyla hastaların \%2,9'unda (26 hasta) ve hastaların \%1,9'unda (17 hasta) görüldü. Altı hastada hipoksi, altı hastada intraoperatif hipotansiyon (iki hastaya vazokonstrüktör desteği uygulandı), on üç hastada postoperatif hipertansiyon (üç hastaya vazodilatatör başlandı, diğer hastalarda ağrı kontrolü sonrası normotansiyon sağlandı), dört hastada alerjik reaksiyon, sekiz hastada laringospazm (bir hasta hipoksi nedeniyle entübe edildi), iki hastada aritmi, iki hastada bulantıkusma, üç hastada hipotermi, iki hastada deliryum, bir hastada hipertermi ve bir hastada hipoglisemi gelişti.

On beş hasta $(\% 1,65)$ çeşitli nedenlerle hastaneye yatııldı. Yedi hasta ek hastalıkları için infüzyon tedavisi başlanması, iki hasta intravenöz antibiyotik tedavisi için, iki hasta uzun operasyon süresi (üç saat üzerinde) nedeniyle, bir hasta laringospazm sonrası entübe edilmesi, bir hasta cerrahi hematom sonrası revizyona alınması, bir hasta hipoglisemi gelişimi ve bir hastada ise ciddi alerjik reaksiyon nedeniyle hastaneye yatışları sağlandı.

Komplikasyon gelişimi açısından risk faktörü olabilecek yaş, vücut kitle indeksi, ek hastalık öyküsü, bazal ortalama tansiyon değeri, bazal kalp hızı, bazal oksijen satürasyonu, kullanılan sıvı miktarı, genel anestezi uygulanıp uygulanmadığı, işlemin endoskopik yapılıp yapılmadığı ve anestezi süresi regresyon modeline dahil edildi. Operasyonun endoskopi ile yapılması (OR:4,357 [1,909-9,943], $p<0,001)$ ve hastanın bazal kalp hızı yüksekliği (OR:1,030 [1,009-1,052], $p=0,006)$ komplikasyon gelişimi ile ilişkili bağımsız risk faktörleri olarak bulundu (Tablo-9).

\section{TARTIŞMA}

Amerika'da Ralph Waters'ın 1900'lerde açtığı ayaktan anestezi kliniği ofis bazlı cerrahinin ilk örneğidir. Gerçek anlamda günübirlik anestezi ise ilk kez 1984'te Society for Ambulatory Anesthesia (SAMBA)'nın kurulmasıyla başlamıştır (4). ABD'de Florida eyaletinde 1998-2008 yılları arasında 1,9 milyon prosedür gerçekleştirilmiş ve bu hastaların \%67,8'ine günübirlik cerrahi uygulandığı saptanmıştır. En sık günübirlik işlem uygulayan klinik göz $(\% 99,7)$ iken, en az uygulayan klinik ise $\% 8,2$ ile kardiyotorasik cerrahi olmuştur (5). Gül ve ark. (6) ise en fazla hastanın genel cerrahide (\%28) alındığını, en sık yapılan ameliyatın ise kitle eksizyonu $(\% 16,5)$ olduğunu bildirmişlerdir.

Hastanemizde ise en yüksek oranda günübirlik işlemler göz ameliyathanesinde gerçekleşti, bunu çocuk cerrahisi ve KBB ameliyathaneleri izledi. En az vaka ise beyin cerrahisi, kalp ve damar cerrahisi ve göğüs cerrahi ameliyathanelerinde gerçekleşti. Göz işlemlerinin çoğunun muayene tarzında (göz dibi muayenesi) ve basit işlemler olması oranın yüksekliğine neden olurken; beyin cerrahisi ve kardiyotorasik cerrahide komplike operasyonların uygulanması ve operasyon sonrası bakım ve monitörizasyon gerekliliği günübirlik cerrahi uygulamalarının az olmasına neden olmuştur.

Günübirlik cerrahi uygulamaları ASA I grubu yanında son dönemlerde ASA II ve ASA III grubunda da uygulanmaya başlanmıştır (7). Ansell ve ark. (8) ASA III grubu hastaların 
postoperatif komplikasyonlar açısından ASA I ve ASA II grubundan farksız olduğunu göstermişlerdir. Gül ve ark (6) ise günübirlik hastaların \%68'sinin ASA I, Chung ve ark. (9) ise genel anestezi uygulanan hastaların \%98'inin ASA I ve II grubunda yer aldığını bildirmişlerdir.

Ameliyathanelerimizde genellikle ASA I (\%52) ve ASA II $(\% 46,5)$ hastalara günübirlik cerrahi uygulandı. ASA III hasta sayısı ise sadece $\% 1,5$ olarak saptandı. Erişkin hastaların çoğunda ek bir hastalığı mevcut idi. En sık görülen hastalıklar $\% 15,7$ ile hipertansiyon ve \%9,8 ile diyabetes mellitus oldu. Yapılan regresyon analizinde ASA grupları ve komplikasyonlar arasında anlamlı ilişki saptanamadı. Bu sonuç ASA III grubu hastaların günübirlik cerrahi için bir dışlama kriteri olmaması gerektiği; iyi bir preoperatif değerlendirme ve yeterli hazırlık ile günübirlik cerrahi olabileceğini gösterdi.

Rejyonel anestezi uygulamaları daha iyi postoperatif ağrı kontrolü, daha düşük postoperatif bulantı-kusma (POBK) riski, potansiyel olarak daha hızı taburculuk ve daha az kronik ağrı sendromu insidansı nedeniyle günübirlik hastalarda avantajlı kabul edilmektedir $(10,11)$. Uzun etkili periferik sinir bloğu mükemmel postoperatif analjezi sağlasa da kullanımı birçok anestezi uzmanı tarafından günübirlik cerrahide tercih edilmemektedir (12). Gül ve ark. (6) hastaların \%32'sine lokal anestezi, \%27'sine genel anestezi, \%19'una monitörize anestezik bakım, \%17'sine spinal anestezi uygulamıştır. Chung ve ark. (9) 17638 günübirlik hastanın \%57,4'üne genel anestezi, \%35,7'sine sedo analjezi (monitörize anestezik bakım), $\% 3,3$ 'üne lokal anestezi, \%2,7'sine rejyonal blok ve \%0,9'una kronik ağrı için blok uyguladıklarını belirtmişlerdir. Genel anestezide propofol (\%97), fentanil (\%74), alfentanil (\%22), midazolam (\%23), volatil anestezikler (\%51) ve nöromuskuler blokörleri (\%20); sedo-analjezi (MAB)'de ise midazolam (\%94), fentanil (\%58), propofol (\%57) ve alfentanili (\%22) kullanmışlardır. Genel anestezide hastaların $\% 1,5^{\prime}$ inde, sedo-analjezide ise hastaların $\% 4,3$ 'ünde komplikasyon gelişmiştir. En sık görülen komplikasyonlar hipertansiyon, aritmi gibi kardiyak kökenliydi (9).

Bizim hastalarda ise genel anestezi $(\% 73,5)$ en sık tercih edilen anestezi yöntemiydi. Rejyonal anestezi ise sadece hastaların \%19,3'ünde uygulandı. Çocuk hastaların çoğunda da genel anestezi tercih edildi. Sadece üç pediatrik hasta rejyonal blok (biri spinal, ikisi aksiller blok) ile opere oldu. Genel anestezide erişkenlerin tamamında propofol, remifentanil veya fentanil, sevofluran veya desfluran tercih edildi. Çocuk hastalarda ise damar yolu olanlarda indüksiyon propofol, olmayanlarda sevofluran ile gerçekleştirildi. Nöromuskuler blokaj için sadece rokuronyum kullanıldı. Lokal anestezik olarak ise spinal anestezide bupivakain, ekstremite bloklarında bupivakain ve prilokain, sedasyon amacıyla da midazolam daha çok tercih edildi. Propofol ve remifentanil gibi ajanların artık etkilerinin olmaması ve hızlı derlenme etkileri, rokuronyumun spesifik antidotu olması nedeniyle günübirlik cerrahide kullanılan ajanlar oldu. Epidural, kombine epidural-spinal teknikler, alt ekstremite blokları uzun etki süreleri nedeniyle taburculuğu geciktirebileceğinden tercih edilmedi. Çok kısa işlemlerde de lokal anestezi yerine maske veya sedo-analjezi tekniklerinin uygulanması taburculuk sürelerinde uzama gibi sorunların artışına engel oldu.

Gül ve ark. (6) postoperatif komplikasyon olarak baş dönmesi, ağrı, bulantı, kusma, hipertansiyon, hipotansiyon geliştiğini ve ek hastalıklar nedeniyle hastaların \%5,9'unun evine taburcu edilemediğini bildirmişlerdir. Chung ve ark. (9) ise postoperatif dönemde ağrı ve bulantı-kusma insidansının sırasıyla genel anestezide $\% 9,5$ ve $\% 7,2$ iken; sedo-analjezide (MAB) ise \%1,4 ve $\% 1,2$ olarak saptamışlardır. Yazarlar aşırı ağrı, postoperatif bulantı-kusma, halsizlik, uyku hali ve kardiyovasküler komplikasyonların hem genel anestezide hem de MAB'ta hastanede kalış süresini uzattığını göstermişlerdir (9).

Günübirlik cerrahi sonrası hastaların \%1-3'ünde postoperatif 30 gün içinde tekrar hastaneye yatış gereksinimi olmaktadır. Tekrar yatışların en sık nedeni cerrahi komplikasyonlardır. En az jinekolojik operasyon, en fazla ürolojik, genel cerrahi ve kulak burun boğaz operasyonları sonrası hastaneye yatış olmaktadır $(13,14)$. Warner ve ark. (15) 45090 hastayı kapsayan çalışmalarında, günübirlik cerrahi sonrası 33 hastada ciddi morbidite veya mortalite (iki hasta miyokard enfarktüsü ve iki hasta trafik kazası) bildirmişlerdir. Major morbidite gelişen 31 hastanın 14'ünde (\%45) miyokard enfarktüsü, 7'sinde (\%23) merkezi sinir sistemi yetersizliği, 
5 'inde (\%16) pulmoner emboli ve 5'inde (\%16) solunum yetmezliği gelişmiştir. Komplikasyonların 4'ü (\%13) ameliyattan sonraki ilk 8 saat içinde, 15 'i (\%48) sonraki 40 saat içinde ve 12 tanesi (\%39) sonraki 28 gün içinde meydana gelmiştir. Yazarlar komplikasyonların üçte birinden fazlasının postoperatif 48 saat veya daha sonra meydana geldiğini; genel morbidite ve mortalite oranlarının çok düşük olduğunu ifade etmişlerdir. Duncan ve ark. (16) ise hastaların \%8'inde PABÜ komplikasyonu yaşadıklarını tespit etmişlerdir. Solunum ve dolaşım komplikasyonlarını sırasıyla $\% 0,4$ ve $\% 0,3$ olarak bulmuşlardır.

Postoperatif hastanede kalış süresi günübirlik cerrahide sonucun değerlendirilmesinde kullanılan önemli parametrelerdir $(8,17)$. Junger ve ark. (17) 3152 hastayı kapsayan çalışmalarında günübirlik vakaların \%13,2'sinin $\leq 3$ saat, \%55,3'ünün 3-6 saat arasında ve $\% 26,2$ 'sinin 6 saat $\geq$ hastanede kaldığını ve beklenmeyen hastane yatışının $\% 5,4$ olduğunu ifade etmişlerdir. Preoperatif hemoglobin değerinin ve intraoperatif kan kaybının uzamış postoperatif kalış için iyi bir gösterge olduğunu belirtmişlerdir. Diğer önemli belirteçler ise kadın cinsiyet, ileri yaş, uzamış cerrahi süresi, yüksek miktarda sıvı infüzyonu, spinal anestezi, intraoperatif opioid ve nöromuskuler blokör kullanımı, yüksek ağrı skorları, bulantı-kusma ve uzun ameliyat bekleme süreleri olarak bulunmuştur. Yazarlar uzamış PABÜ ve hastanede kalma sürelerinin cerrahi prosedürlerle ilişkili olduğuna karar vermişlerdir. Ansell ve ark. (8) ise anesteziye bağı komplikasyonların ileri yaş, yandaş hastalıklar ve intraoperatif hipoksi ile ilişkili olduğunu belirtmişlerdir. Chung ve ark. (18) ise postoperatif ağrının uzamış hastane yatışına ve hastaların beklenmedik hastaneye kabulü için yaygın bir neden olduğunu ifade etmişlerdir. On bin sekiz hasta incelendiğinde şiddetli ağrı insidansı PABÜ'da \%5,3, cerrahi günübirlik servisinde $\% 1,7$ ve tüm hastalarda postoperatif 24'üncü saatte \%5,3 olarak saptanmıştır. Genç erkekler, ASA I hastalar ve daha yüksek vücut kitle indeksi olan hastalarda şiddetli ağrı insidansı daha yüksekmiş. Şiddetli ağrısı olan grupta, anestezi süresi, PABÜ ve cerrahi bakım ünitesinde kalma süresi ve taburcu olma süresi şiddetli ağrısı olmayan gruptan daha uzunmuş. En yüksek ağrı insidansına sahip ameliyatlar ortopedik $(\% 16,1)$, ürolojik $(\% 13,4)$, genel cerrahi $(\% 11,5)$ ve plastik cerrahi $(\% 10)$ olarak sıralanmıştır. Genel anestezi uygulanan hastalarda intraoperatif fentanil dozu, şiddetli ağrılı grupta ağrısız gruba göre anlamlı derecede düşük saptanmıştır.

Hastalarımızın \%60,2'sinde postoperatif analjezik intiyacı olmadı. Hastaların \%19,3'ünde rejyonal blok ve \%4,7'sinde periferik bloklar postoperatif analjezi amacıyla kullanıldı. Orta veya ciddi ağrı hastaların \%13,6'sında görüldü ve bu hastalarda ağrı kontrolü amacıyla tramadol (\%13) ve morfin $(\% 0,6)$ kullanıldı. Daha basit ağrı durumunda ise parasetamol ve non-steroid anti-inflamatuvar ilaçlar tercih edildi. Pediyatrik hasta grubunda ise indüksiyon sonrası ketamin $(0,5 \mathrm{mg} / \mathrm{kg})$ postoperatif analjezi amacıyla uygulandı. Günübirlik hastaların $\% 4,5$ 'inde (41 hastada 44 komplikasyon) en az bir komplikasyon saptandı. İntraoperatif komplikasyonlardan en sık görülenler hipotansiyon, hipoksi ve laringospazm iken, postoperatif dönemde ise hipertansiyon, alerjik reaksiyon ve hipotermi daha fazla görüldü. Buna rağmen hastaların sadece \%1,65'inde beklenmeyen hastane yatışı gerçekleşti. Hastane yatışı yapılan hastaların çoğunda ek hastalık mevcut idi. Sadece bir hasta laringospazma bağlı gelişen negatif basınçlı akciğer ödemi dolayısıyla entübe olarak yoğun bakımda izlendi. Mortalite ile seyreden olgumuz olmadı.

Operasyon sonrası komplikasyon nedeniyle hastaneye en fazla yatış yapılan üç klinik sırasıyla çocuk cerrahisi, üroloji ve genel cerrahi olarak saptandı. Pediyatrik hastalarda laringospazm, alerjik reaksiyonlar, hipoglisemi en sık yatış sebebi iken, erişkin hastalarda hipertansiyon en sık nedendi. Komplikasyonlarla ilişkili risk faktörleri araştırıldığında literatürden farklı olarak yaşın, cinsiyetin, ASA skorunun, verilen sıvı miktarının, anestezi tipinin önemli olmadığını saptadık. İşlemin endoskopik olarak gerçekleşmesi ve bazal kalp hızının yüksek oluşu komplikasyonlar için bağımsız risk faktörü olarak saptandı. İşlemin endoskopik yapılması ile hastalarda foley veya nazogastrik sonda uygulanmakta ve işlem süresi 60 dakikanın üzerine çıkmaktadır. Bu nedenle işlem süreleri uzamakta ve buna bağlı olarak komplikasyonlarda artış olmaktadır. Pediyatrik yaş grubunda hastaların \%26,8'ini oluşturmasına rağmen komplikasyonların \%50'si bu grupta gelişti. Kalp atım hızının bu grupta erişkinlere göre daha yüksek olması komplikasyonlar için kalp hızının risk faktörü olmasına neden oldu. 
$\mathrm{Bu}$ çalışmanın çeşitli kısıtılıkları mevcuttur: Öncelikle çalışma bir aylık bir dönemdeki kesitsel hastalarımızdan oluşmakta idi ve prospektif gözlemsel olarak kurgulandı. İkincisi sadece ameliyathane işlemleri dâhil edildi. Ameliyathane dışı işlemlerin verilerine ulaşım sıkıntısı ve diğer dâhili kliniklerin anestezist olmadan sedasyon uygulamaları nedeniyle ameliyathane dışı işlemler bu çalışmaya dâhil edilemedi. Üçüncüsü cerrahın tek başına uyguladığı ve anestezistin eşlik etmediği lokal anestezi ile yapılan ameliyathane işlemlerinin verileri toplanamadığından çalışmaya dahil edilmedi. Son olarak da bu çalışmada komplikasyonlarla ilişkili risk faktörleri ve beklenmeyen hastane yatışı çalışılmasına rağmen, taburculuk sonrası bir ay içinde gerçekleşen yeniden hastane kabulleri çalışılamadı.

\section{SONUÇ}

Tıbbi teknolojideki gelişmeler günübirlik cerrahi uygulamalarında hızlı bir artışa neden olmuştur. Hızlı ve kısa etkili anesteziklerin, analjeziklerin ve nöromuskuler blokörlerin yanı sıra geliştirilmiş anestezi cihazları ve monitörizasyon yöntemlerinin kullanımı hastaların iyileşme dönemlerinde anestezi komplikasyonlarını azaltmıştır. Postoperatif komplikasyonlar (ağrı, bulantı-kusma gibi) nadir olmayıp; iyileşmeyi geciktirirler ve hastane yatışlarında artışa neden olurlar. Biz bu çalışmada operasyonun endoskopik uygulanması ve yüksek kalp hızı olan bireylerde komplikasyon oranlarının daha yüksek olduğunu saptadık fakat anestezi yöntemi ile komplikasyonlar arasında anlamlı ilişki bulamadık. Günübirlik olgularda anestezi yönteminden bağımsız olarak iyi bir intraoperatif yaklaşım ile komplikasyonlarda azalma sağlanabileceği sonucuna varılmıştır.

Çıkar çatışması: Bu yayına ilişkin yazarların her hangi bir çıkar çatışması yoktur.

\section{Kaynaklar}

1. Okocha O, Gerlach RM, Sweitzer B. Preoperative Evaluation for Ambulatory Anesthesia: What, When, and How? Anesthesiol Clin. 2019; 37 (2): 195-213.

2. Seligson E, Beutler SS, Urman RD. Office-based anesthesia: an update on safety and outcomes (2017-2019). Curr Opin Anaesthesiol. 2019; 32 (6): 756-61.

3. Preoperatif Hazırlık, TARD Anestezi Uygulamaları Kılavuzları, Türk Anesteziyoloji ve Reanimasyon Derneği (TARD), 2015. Erişim tarihi: 01.07.2020, Erişim https://www.tard.org.tr/assets/kilavuz/preoperatifdegerlendirme.pdf

4. White PF, Freire AR. Ambulatory (Outpatient) Anesthesia in: Miller RD (ed) Miller's Anesthesia Elsevier Churchill Livingstone, USA 6th ed, 2005; 2589-637.

5. Hollingsworth JM, Birkmeyer JD, Ye Z, Miller DC. Specialty-specific trends in the prevalence and distribution of outpatient surgery: implications for payment and delivery system reforms. Surg Innov. 2014; 21 (6): 560-5.

6. Gül R, Göksu S, Mızrak A, Koruk S, Öner Ü. Günübirlik cerrahi ünitemizde ilk sekiz aylık uygulamalarımız. Gaziantep Tıp. Dergisi 2008; 14 (2): 23-7.

7. Friedman Z, Chung F, Wong DT, Canadian Anesthesiologists' Society. Ambulatory Surgery Adult Patient Selection Criteria - A Survey of Canadian Anesthesiologists. Can J Anaesth. 2004; 51 (5): 437-43.

8. Ansell GL, Montgomery JE. Outcome of ASA III Patients Undergoing Day Case Surgery. Br J Anaesth. 2004; $92(1): 71-4$.

9. Chung F, Mezei G. Factors contributing to a prolonged stay after ambulatory surgery. Anesth Analg. $1999 ; 89$ (6): 1352-9.

10. Williams BA, Beaman ST, Kentor ML. Regional anesthesia group practice in the university hospital setting and ambulatory/regional anesthesia Clinical pathway formulation. Int Anesthesiol Clin. 2005; 43 (3):3-13.

11. Liu SS, Strodtbeck WM, Richman JM, Wu CL. A comparison of regional versus general anesthesia for ambulatory anesthesia: a meta-analysis of randomized controlled trials. Anesth Analg. 2005; 101 (6): $1634-42$. 
12. Klein SM, Pietrobon R, Nielsen KC, Warner DS, Greengrass RA, Steele SM. Peripheral nerve blockade with long-acting local anesthetics: a survey of the Society for Ambulatory Anesthesia. Anesth Analg. $2002 ; 94$ (1): 71-6.

13. Mezei G, Chung F. Return hospital visits and hospital readmissions after ambulatory surgery. Ann Surg.1999; $230(5): 721-7$.

14. Twersky R, Fishman D, Homel P. What happens after discharge? Return hospital visits after ambulatory surgery. Anesth Analg.1997; 84 (2): 319-24.

15. Warner MA, Shields SE, Chute CG. Major morbidity and mortality within 1 month of ambulatory surgery and ansthesia. JAMA 1993; 270 (12): 1437-41.

16. Coley KC, Williams BA, DaPos SV, Chen C, Smith RB. Retrospective evaluation of unanticipated admissions and readmissions after same day surgery and associated costs. J Clin Anesth. 2002; 14 (5): 349-53.

17. Junger A, Klasen J, Benson $\mathrm{M}$, et al. Factors determining length of stay of surgical day-case patients. Eur $\mathrm{J}$ Anaesthesiol. 2001; 18 (5): 314-21.

18. Chung F, Ritchie E, Su J. Postoperative pain in ambulatory surgery. Anesth Analg. 1997; 85 (4): 808-16. 